\title{
A simple, but useful, application of image analysis
}

\author{
Eugene F. Stoermer \\ Center for Great Lakes, University of Michigan, Ann Arbor, MI 48109-2099, USA (email: stoermer@umich.edu)
}

Received 28 April 1995; accepted 29 June 1995

\begin{abstract}
\section{Introduction}

New technologies often engender unanticipated applications. In some instances these applications allow novel insights. In other cases, they simplify or improve accuracy of common tasks.

For some time we have used image analysis to investigate problems in taxonomy (Stoermer \& Ladewski, 1982; Mou \& Stoermer, 1992), biogeography (Stoermer et al., 1986) and ecology (Stoermer et al., 1985). Availability of this technology has led to many applications we did not originally anticipate. In this note I discuss an application that makes routine identification, the fundamental basis of microfossilbased paleolimnology (Imbrie \& Kipp 1971; Birks 1994), of diatoms, easier and more accurate.
\end{abstract}

Available image analysis tools are useful aids to some common tasks necessary for diatom identification. In particular, availability of this technology allows easier and more certain enumeration of closely spaced and difficult to resolve striae. Dimensional information may also be easily and accurately measured and recorded.

\section{Materials and methods}

Material described was cleaned in hot $\mathrm{HNO}_{3}$ and potassium dichromate and mounted in Hyrax ${ }^{\circledR}$. Optical system used is a Leitz Dialux 20 microscope equipped with a NPL Fluortar $100 \mathrm{X}, 1.32$ oil immersion objective and immersible condenser.

Image capture hardware consists of a Panasonic CCTV camera model WV1410 driving a Data Translation Quick Capture Card frame grabber in a Macintosh Centris 650 computer, equipped with 8 Megabytes RAM and a 500 Megabyte hard drive.

Software used is the public domain NIH Image program (version 1.54), written by Wayne Rasband at the U. S. National Institutes of Health, and available from the Internet by anonymous ftp from zippy.nimh.nih.gov or on floppy disk from NTIS, 5285 Port Royal Rd, Springfield, VA 22161 USA, part number PB93-504868. NIH Image is a full-featured analysis package which is used by investigators in a number of disciplines. For those interested, a mail list is maintained which provides information on a wide range of applications, answers to questions, and current updates and developments. To subscribe, send an e-mail message containing the single line <subscribe nih-image (your first name) (your last name) to listserv@soils.umn.edu. Instructions on how to retrieve archived messages via e-mail, FTP, and GOPHER are included in a welcome message.

Prior to taking measurements, measurement functions were calibrated using a Bausch and Lomb precision stage micrometer 370 and the NIH Image 'set scale' function.

\section{Results}

Figure 1 is a screen dump of a captured 1000X field, as displayed by NIH Image. Available image analysis tools are shown on the left side of the screen. Standard Macintosh menu items are displayed at the top of the screen. The main screen contains partial images of two diatoms, Asterionella formosa Hass. (upper), and Amphipleura pellucida (Kütz.) Kütz. (lower), and two tool windows. The window in the lower right corner, labeled 'Map', is used to adjust brightness and 


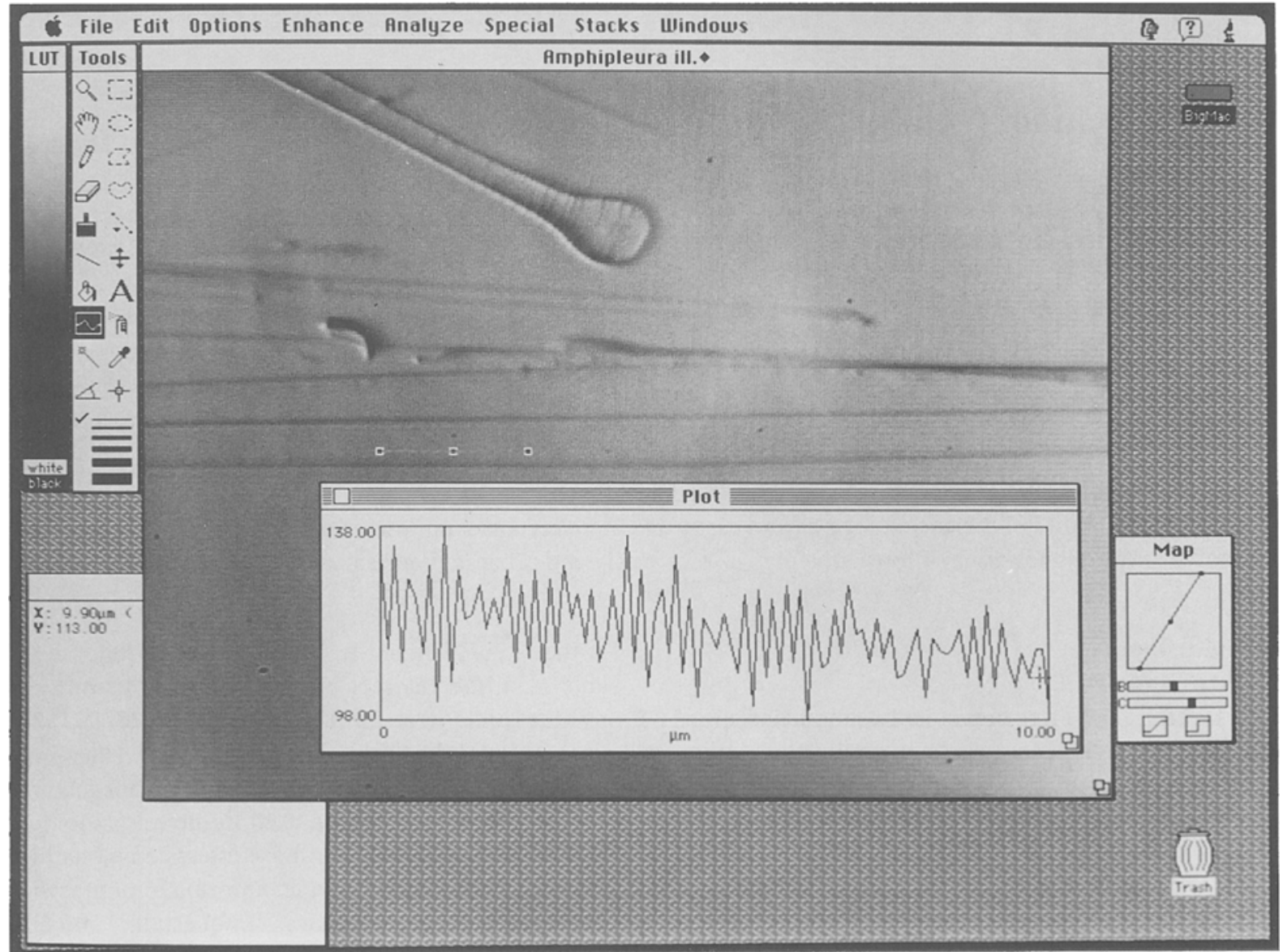

Fig. 1. Screen from NIH Image program showing configuration and measurement windows. See text for complete explanation.

contrast of the image. The elongated window in the lower half of the screen labeled 'Plot', displays results of density profile measurements, discussed below. The dashed line superimposed on the Amphipleura image indicates a $10.0 \mu \mathrm{m}$ measurement perpendicular to the striae, using the Density Profile Tool (darkened icon on tool bar at right). The measurement is extended to $10.1 \mu \mathrm{m}$ to mitigate ambiguity concerning number of peaks included. The Density Profile Tool generates a density profile plot of the area crossed by the measurement line. Note that the mean density decreases from left to right. This is due to the fact that illumination was slightly oblique to provide maximum contrast in the striae. Also note that there are 40 individual peaks in the density profile. This corresponds to the number of striae in $A$. pellucida, as measured with electron microscopy (Stoermer \& Pankratz, 1964). Stria number in this species is remarkably constant, and it has been used as a test object for high quality light micro- scopes (Woodward, 1871; Biscoe, 1873; Van Heurck, 1880-1885; Fraenkel \& Pfieffer, 1889; Köhler, 1909; Trivelli \& Linke, 1932) and early electron microscopes (Kolbe \& Golz, 1943; Ockenden, 1945; Nielsen, 1947; Locquin, 1950).

\section{Discussion}

Truly accurate and reproducible counts of striae on finely structured diatoms is a challenge for several reasons. Not all investigators working in paleolimnology have access to very high resolution microscopes. Indeed, a microscope adjusted for optimal resolution is somewhat inconvenient to use for routine enumeration because of limited contrast and depth of field. Even given a high quality instrument and contrast enhancement appliances, human frailties, both physical and mental, impinge on the measurement process. Some 
of my steely-eyed colleagues may be able to count more than 35 striae in $10 \mu \mathrm{m}$ with routine accuracy, but those of us afflicted by unsteady focus, 'floaters', and short attention span sometimes reach less than certain conclusions. This being the case, the temptation to accept the number given in a description is not inconsequential. Fortunately, computers are supremely dumb devices, hence lack human physical and mental frailties. They merely accept whatever input is provided, and record it. If minimum assurances of a constant physical setup and appropriate calibration are provided, measurements of the same quality may be made and recorded rapidly and with certainty. That is not to say the human element is completely negated. Some might interpret the simple density profile in Figure 1 differently than I have. However, I am very confident that they could convince themselves that 40 is the true number of peaks by making multiple measurements and subjecting the results to any appropriate statistical test, should they care to. Indeed, the real power of image analysis technology is that it allows easy and routine capture of taxonomic data with very minimal expense.

This brings me to the last argument, which I am sure some of my more conservative colleagues will bring up - the 'hunting mice with an elephant gun' analogy. Indeed, there are other ways to obtain accurate and reproducible measurements of striae on difficult diatoms. One can take a photograph (calibrated), print it (with calibration), and manually measure the results. It is also possible to carefully set up a camera lucida, draw the striae, then count them. The point I wish to make is that image analysis is, by far, the fastest, least expensive, and most certain of these options. In the modern world, electronic image capture hardware is significantly less expensive than mechanical cameras, and there are numerous tools, such as NIH Image, available for little or no expense via the Internet. Some suggested starting points for those who have not already explored this domain are the University of Michigan software archives available via Gopher and SUNY image analysis software archives available via the World Wide Web (http://life.bio.suny.edu//software.html).

\section{Acknowledgements}

I thank Mark Edlund for reading the manuscript and pointing out corrections and clarifications. Research leading to this publication was supported by NSF Grant EAR-9119537.

\section{References}

Birks, H.J.B., 1994. The importance of pollen and diatom taxonomic precision in quantitative palaeoenvironmental reconstructions. Rev. Palaeobot. Palynol. 83: 107-117.

Biscoe, J.D., 1873. Amphipleura pellucida by moonlight. Am. Nat. 7: 55.

Fraenkel, C. \& R. Pfieffer, 1889. Mikrophotographisches Atlas der Bakterienkunde. Verlag A. Hirchwald, Berlin.

Imbrie, J. \& N. G. Kipp, 1971. A new micropaleontological method for quantitative paleoclimatology: application to a late Pleistocene Caribbean core. pp. 71-181. In; K.K. Turekian (ed.), The Late Cenozoic Glacial Ages. Yale Univ. Press, New Haven.

Köhler, A., 1909. Aufnahmen von Diatomeen mit ultraviolettem Licht. Eder's Jahrb. 23: 60-67.

Kolbe, R. \& E. Golz, 1943. Elektronenoptische Diatomeen Studien. Ber. Deutsch. Bot. Ges. 61: 91-98.

Locquin, M., 1950. Structure fine des frustules de la diatomé Amphipleura pellucida. Proc. First Internal. Congress Electron Microscopy.

Mou, D., \& E. F. Stoermer, 1992. Separating Tabellaria (Bacillariophyceae) shape groups: A large sample approach based on Fourier descriptor analysis. J. Phycol. 28: 386-395.

Nielsen, J.E., 1947. Electron microscope reveals a possible structure of Amphipleura pellucida. Trans. Amer. Microsc. Soc. 66: 140143.

Ockenden F.E.J., 1945. The President's address. Introduction to the electron microscope. J. Quek. Microsc. Club, ser. 4, 2: 43-62.

Stoermer, E.F., \& T. B. Ladewski, 1982. Quantitative analysis of shape variation in type and modern populations of Gomphoneis herculeana. Nova Hedwigia, Beih. 73: 347-386.

Stoermer, E.F., \& H. S. Pankratz, 1964. Fine structure of the diatom Amphipleura pellucida. I. Wall structure. Amer. J. Bot. 51: 986990.

Stoermer, E.F., J.A. Wolin, C.L. Schelske, \& D.J. Conley. 1985. Variations in Melosira islandica valve morphology in Lake Ontario sediments related to eutrophication and silica depletion. Limnol. Oceanogr. 30: 414 418 .

Stoermer, E.F., Y.-Z. Qi \& T.B. Ladewski, 1986. A quantitative investigation of shape variation in Didymosphenia (Lyngb. ) $\mathrm{M}$. Schmidt. Phycologia 25: 494-502.

Trivelli, A.P.H. \& E. Linke, 1932. Photomicrography of Amphipleura pellucida. J. Roy. Microsc. Soc. 52: 25-29.

Van Heurck, H., 1880-1885. Synopsis des Diatomées de Belgique. Imprimie J. Ducaju \& Cie, Anvers.

Woodward, J.J., 1871. Memorandum on the structure of Amphipleura pellucida. Am. J. Sci, Arts, ser 3, 1: 345-346. 